\title{
動眼神経の単独麻痺で発症した蝶形骨洞神経鞘腫の一例
}

中国労災病院耳鼻咽喉科

田 代亭

中国労災病院病理部

西田 俊 博
渡部浩杉本一郎

\section{A CASE OF SPHENOID SINUS NEURINOMA WITH PARALYSIS OF THE OCULOMOTOR NERVE}

\author{
Toru Tashiro ${ }^{1)}$, Hiroshi Watanabe ${ }^{1)}$, Ichiro Sugimoto ${ }^{1)}$, \\ Toshihiro Nishida ${ }^{2)}$
}
${ }^{1)}$ Department of Otorhinolaryngology, Chugoku Rousai General Hospital, Hiroshima ${ }^{2}$ Department of Pathology, Chugoku Rousai General Hospital, Hiroshima

\begin{abstract}
A 75-year-old man developed left side ptosis and double vision. Opthalmological examination showed this to be due to disturbance of the left oculomotor nerve. The left nasal cavity was filled with a mass lesion. In computed tomography and magnetic resonance imaging, a shadow was observed in the left posterior ethmoid and sphenoid sinuses. Endoscopic sinus surgery and pathological examination revealed neurinoma. The tumor was mostly resected by a microdebritter. The postoperative course was satisfactory. The patient has recovered fully from oculomotor nerve palsy and has had no recurrence in the 21 months postoperatively.
\end{abstract}

Key words : sphenoid sinus neurinoma, disturbance of the left oculomotor nerve, endoscopic sinus surgery, micro-debritter system

はじめに

神経鞘腫は，シュワン細胞から発生し，シュワン細胞 を欠く嗅神経と視神経以外のあらゆる神経から発生する 可能性がある。耳鼻咽喉科領域では聴神経に多く，その 他では舌, 頝部, 咽頭, 喉頭にみられるが鼻副鼻腔に発 生することは稀である。

今回我々は, 動眼神経の単独麻痺で発症した蝶形骨洞 神経鞘腫の一例を経験した。そして鼻内視鏡下に，マイ クロデブリッターシステムを用いて腫瘍を摘出し, 良好 な結果を得たので文献的考察を加え報告する。

症例

患者：75才，男性。

主訴：複視, 左眼瞼下垂。

既往歴，家族歴：特記すべきことなし。

現病歴: 平成 11 年 2 月 16 日起床時, 複視, 左眼瞼下 垂を認めた。近医眼科を受診したところ左動眼神経麻痺 を指摘された。近医脳神経外科を紹介されCT, MRIを施 行したところ左蝶形骨洞に異常陰影を認め, 2 月 22 日に 当科を紹介された。

初診時所見 : 複視, 左眼瞼下垂を認めた。鼻内には, 左中鼻道付近から突出する死白色調のポリープ様病変を

認めた（図 1 )。 


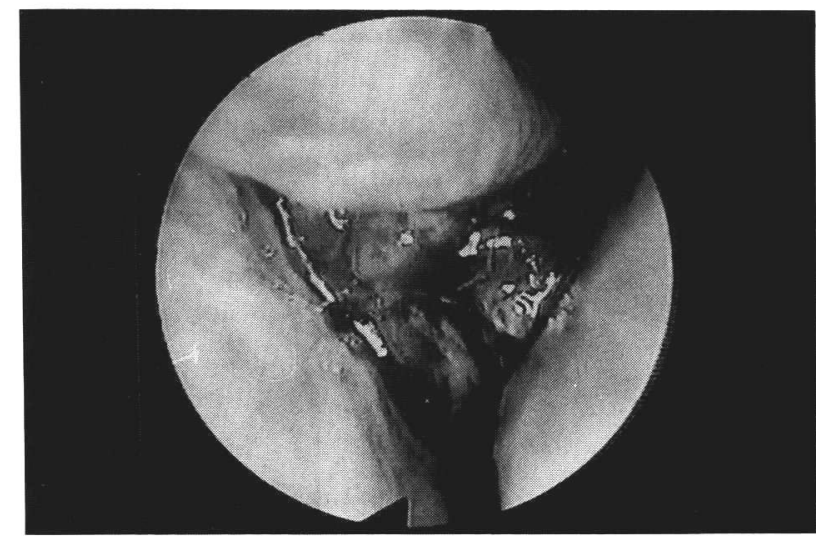

図 1 初殓時の鼻内所見 左中鼻道付近から突出する灰白色調のポリープ 様病変を認める。

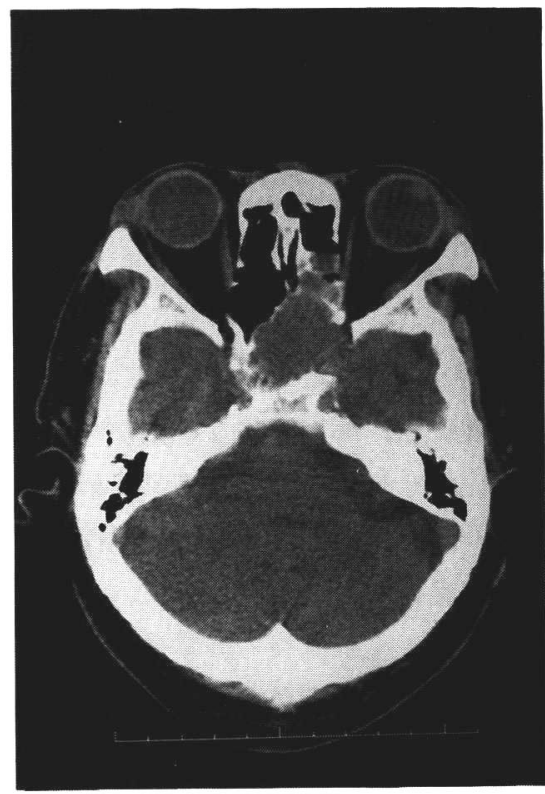

図 2 初診時の副鼻腔単純 C T像 左篩骨洞後部から蝶形骨洞に 広がる, 内部均一で境界明瞭 な陰影を認め, 蝶形骨洞側壁 の一部に骨欠損を認める。

画像所見：単純CTでは左篩骨洞後部から蝶形骨洞に 広がる，内部均一で境界明瞭な陰影を認め，蝶形骨洞側 壁の一部に骨欠損を認めた(図 2 )。MRIでは，左鼻腔か ら篩骨洞及び蝶形骨洞上方にかけてT1強調像にて低信 号，T2強調像で著明な高信号を呈し，ゆるやかな造影効 果を示す病変を認め,ポリープなどが考えられた。また， 左篩骨洞後部から蝶形骨洞には，T1及びT2強調像で著 明に高信号を呈する病変を認め, それらは粘調度の高い 液体貯留が考えられた（図 3 )。

入院経過：2月 23 日, 局所麻酔下にて鼻内視鏡下, 左

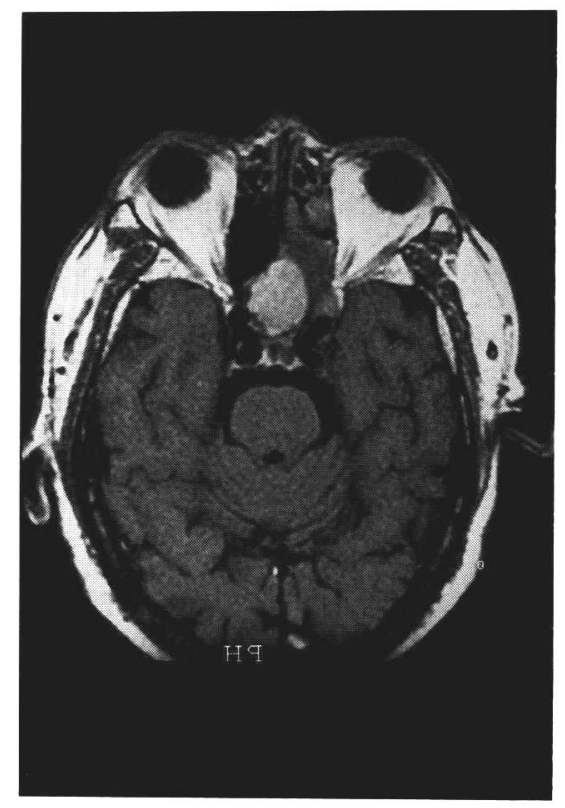

図 3 初診時の副鼻腔MRIT1強調画像 左鼻腔から篩骨洞及び蝶形骨洞上 方にかけて低信号，また，左篩骨 洞後部から蝶形骨洞には，著明に 高信号を呈する病変を認め，それ らはポリープや粘調度の高い液体 貯留が考えられた。

後部篩骨洞から蝶形骨洞の開放を行なった。篩骨洞内は 白色調のポリープ様病変で充満していた。これらを迅速 病理検查に提出した結果ポリープであったので, マイク ロデブリッターシステムにて可及的に切除した。続いて 蝶形骨洞を開放したところ, 膿様の液体貯留を認めた。 蝶形骨洞内にポリープ状の部を認めたが, 術後の消炎に よる改善を期待し操作を加えず手術を終了した。手後直 後からステロイド及び抗菌剤の投与を行い，動眼神経麻 痺は著明に改善した。しかしその後も時々, 突発的に出 現し，すぐに消失する複視を認めた。篩骨洞内のポリー プ様病変の永久病理検査の結果は神経鞘腫であった。

術後に, CTを施行したところ, 左蝶形骨洞の一部に陰 影を認めた (図 4)。また，鼻内視鏡下にて観察したとこ 了, 左蝶形骨洞外側上方に残存する, 充実性, 白色調の 腫瘍を認めた (図 5 )。再手術を検討し，部位的に腫瘍の 全摘は難しいと考え，4月 30 日,再び腫瘍をマイクロデ ブリッターシステムにて可及的に摘出した。術後, 一週 間頃から発作性の複視の頻度が減少し，やがて症状は消 失した。術中, 腫瘍の一部を永久病理検査に提出したが 結果は神経鞘腫であった。術後にCTを施行したところ, 蝶形骨洞内に一部陰影の残存を認めたが（図6), 術後 21 ケ月目の平成 13 年 1 月現在, 明らかな再発及び, 動眼 


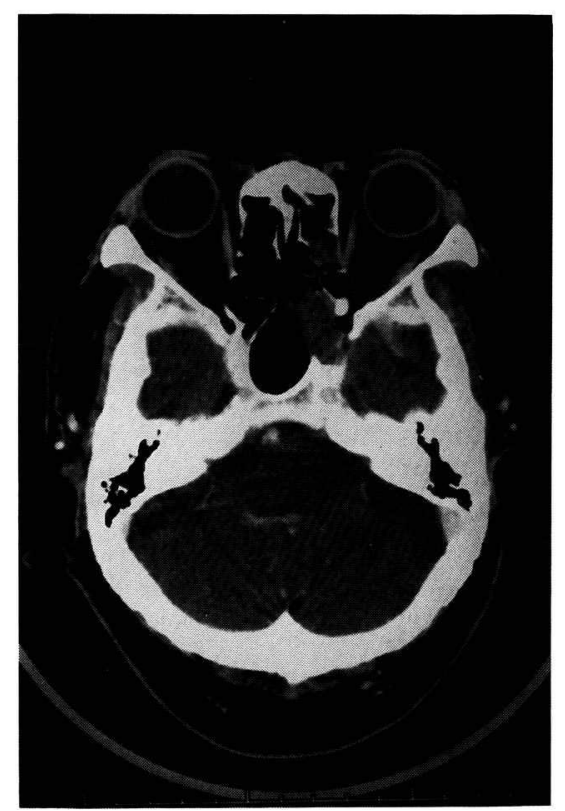

図 4 初回手術後の副鼻舼造影CT像 左蝶形骨洞の一部に陰影を認める。

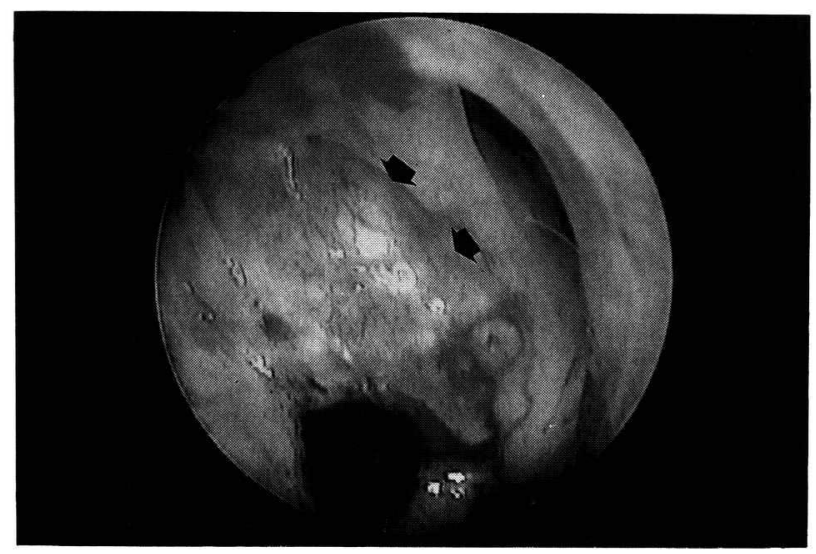

図 5 初回手術後の舅内視鏡所見

矢印：左蝶形骨洞外側上方に残存する,充実性, 白色調の腫演を認める。

神経麻痺, 複視を認めず, また定期的にCTを施行してい るが蝶形骨洞の陰影増大も諗めず良好な結果が得られて いる。

病理組織像：HE染色では, 紡錘形の細胞が束状に増 殖している(図 7-A)。また，S-100タンパク抗体を用い た免疫組織化学検査では，ほとんどの細胞が陽性であっ た（図 7-B)。以上からAntoni A型が主体の神経鞘腫と 診断した。

\section{考察}

動眼神経麻痺は, 脳動脈瘤, 糖尿病, 外傷, 梅毒, 脳 腫瘍などが原因となることが知られている ${ }^{1)}$ が, 後部副

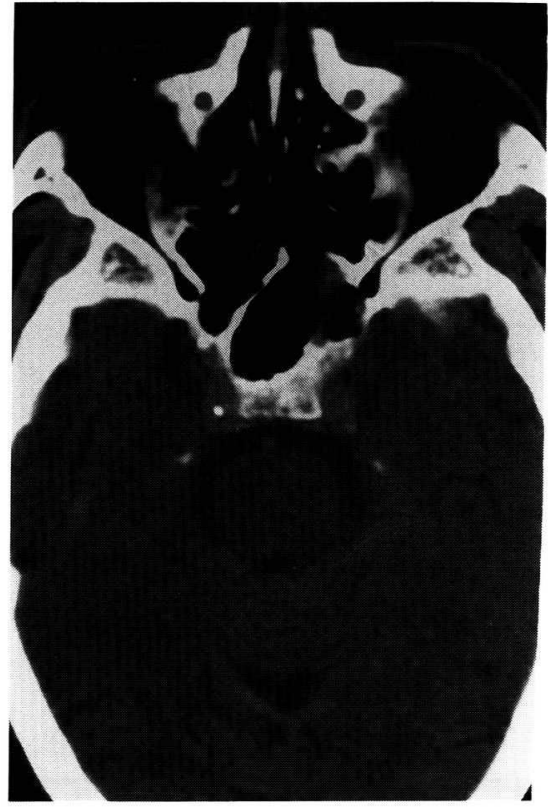

図 6 再手術後の副鼻腔CT像 左蝶形骨洞の一部に陰影の残 存を認めるが，現在まで陰影 の増大は註めず，また明らか な再発も認めていない。

鼻腔疾患が原因となることも忘れてはならない。蝶形骨 洞に発生した腫場は，解剖学的な理由から，進展様式に よって多彩な症状を呈する。その中で，最も頻度の多い 臨床症状は視力障害である2”。一方, 動眼神経, 滑車神経, 外転神経は, 三叉神経第 1 枝とともに, 中頭蓋窩から海 綿静脈洞を通過し，上眼窩裂で非常に接近し眼窩内に入 る為，これらの神経が同時に障害されることも多く，上 眼窝裂症候群として扱われている。今回の症例は，視力 障害を認めず，症状は動眼神経の単独麻瘦であった。

過去の文献では, 蝶形骨洞㖶胞において動眼神経麻㽻 が単独で起こりうる成因が考察されている。笹森らは, 蝶形骨洞の発育が良好で，気泡化が蝶形骨洞前床突起ま で進むと，動眼神経が薄い骨壁を境とし，蝶形骨洞に接 するようになり，その結果睢胞の圧迫で障害を受けやす い状態になる為 ${ }^{3)}$, と報告し, またNormanらは, 蝶形骨 洞の後半部ではその骨壁に沿って走行しているのは動眼 神経のみである為, 䨢胞が蝶形骨洞の後外側に進展する と容易に圧迫をうけ，動眼神経単独麻瘏の成因になる4), と報告している。我々の症例でも, CT上, 蝶形骨洞の発 育は良好で，また，側壁の骨が欠損しており，骨壁に沿っ て走行している動眼神経が，腫瘍の圧迫または炎症によ り障害されたと推定できる。また，腫晹が蝶形骨洞自然 口を閉鎖したことによって生じた急性副鼻腔炎による圧 迫により，症状の増悪を呈したと考えられた。また視力 


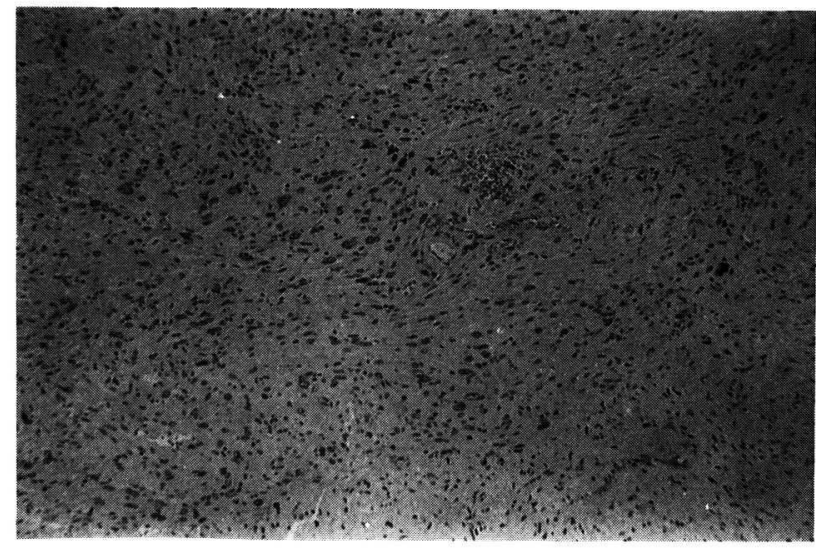

A

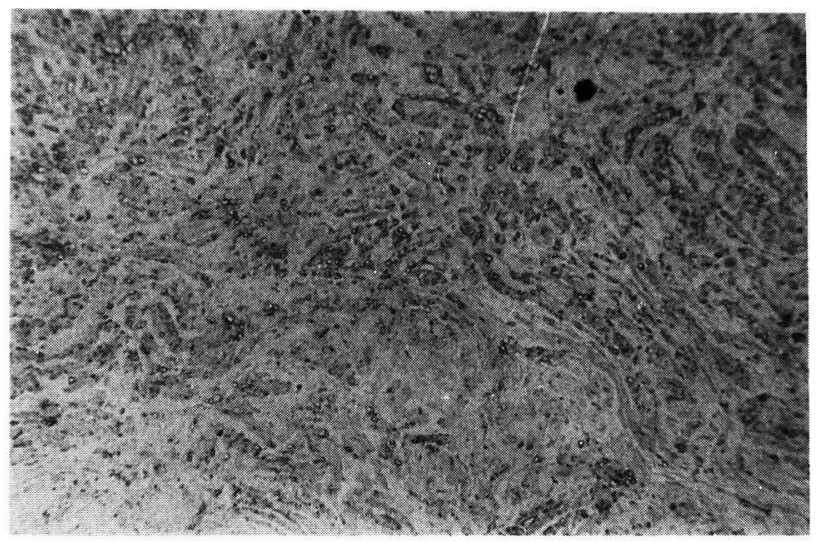

B

図 7 病理組織像

A : H-E染色 $(\times 50)$

B : 免疫組織化学検査 $($ S-100タンパク抗体 $)(\times 50)$

障害を認めなかった成因として，山岡らは，副鼻腔輂胞 は一般に術後性であることが多く, 骨の変形や肉芽新生 が囊胞の発生に関与しているが, 原発性の場合, 視神経 管に囊胞発生前の骨変化等がなく視力が保持されやすい 為 ${ }^{5}$ と考察している。我々の症例も過去に副鼻腔炎の手 術既往はなく，また腫瘍が良性であった為, 視神経管が 保存され視力障害を呈しなかったと推定できる。

神経䩗腫は耳鼻咽喉科領域では聴神経に発生しやす く,その他では舌, 頝部, 咽頭, 喉頭にみられるが鼻副 鼻腔の神経鞘腫に遭遇することは比較的稀で過去 60 余 例の報告しかない ${ }^{6 \sim 8)}$ 。部位は鼻腔, 上靧洞, 篩骨洞の順 に多いとの報告があるが9,10), 蝶形骨洞の報告は過去にな W。

組織学的には，紡鍾形細胞が細胞の束をつくって不規 則に交錯するAntoniA型とよばれる部分を認め，核がし ばしば並列し特徵的な柟状配列 (palisading)を示す。ま た，変成した網状細胞が細胞間に粘液を含む小囊胞を形 成するAntoniB型とよばれる部分を共有することも多 い。また免疫組織学的にはシュワン細胞由来の腫劰であ るため S-100タンパク陽性である。

また，発生神経については，鼻副鼻腔の場合，一般的 に三叉神経第 1 枝，第 2 枝，自律神経末梢枝とされてい るが, 同定できることは少ないようである ${ }^{11212)}$ 。本例は, 腫瘍の部位, 臨床症状より動眼神経からの発生も考えら れるが，確証は得られていない。

治療は外科的切除のみである。腫瘍は再発したり, 稀 に悪性化することがあるので完全に摘出することが望ま しい ${ }^{13,14)}$ 。しかし手術の際に重要なことは,十分な視野を 確保すること ${ }^{15)}$, 合併症をなるべく避けること等である。
従って術式も腫瘍の部位によって異なってくる。鼻副鼻 腔領域の神経鞘腫は末梢枝由来のことが多く, 術後の神 経脱落症状が起きることは少ない。術後の神経脱落症状 がよく問題になるのが,耳下腺内の顔面神経鞘腫である。 腫演を完全に切除するには顔面神経の損傷は避けられな いが, 術後の顔面神経麻痺による患者の苦痛は大きい。 そこで, 神経鞘腫は良性腫瘍であり，悪性化の可能性は あるものの, その頻度は極めて低いこと，また不完全な 摘出でも再発は少ないということを考え, 耳下腺内の顔 面神経鞘腫の場合，先ずは顔面神経を温存した被膜下で の腫瘍の可及的な切除を行うことが適当である, という 報告もされている ${ }^{16)}$ 。本例は腫崵が動眼神経由来の可能 性も否定できず, 術中の動眼神経の損傷が懸念されたこ と, そして蝶形骨洞の一部に骨欠損を認め, 頭蓋内合併 症の危険性があったことから，マイクロデブリッターシ ステムを使用し腫場を被膜下で可及的に摘出するにとど めた。また鼻内視鏡を用いることによって蝶形骨洞内の 良好な視界が得られ，合併症を起こすことなく，腫瘍を 十分に摘出することができたと思われる。

本例は現在まで明らかな再発は認めていないが，今後 も十分な経過観察を行う必要があると思われる。

\section{参考文献}

1) Green WR, Hackett ER, Schlezinger NS: Neuroopthalmologic evaluation of oculomotor nerve paralysis. Arch Opthalmol 72 : 154-167, 1964.

2) 森山寛, 島田和哉, 齐藤 建, 他: 後部副鼻腔襄 腫。耳展 $24 ： 465-480 ， 1981$.

3）笹森史郎, 渡部敏明, 大和田健司, 他：動眼神経麻 
痺を主症状とした後部副鼻腔囊胞の一症例.耳喉頭 頝 $65 ： 391-394,1993$.

4) Norman PS, Yanagawa E: Mucocele of the sphenoid sinus. Arch Otolaryngol 79: 646-652, 1964.

5 ) 山岡俊哉, 佐藤信次, 柴田晶子, 他：動眼神経麻痺 を呈した原発性蝶形骨洞囊胞の一症例. 大警病医誌 $17: 139-142,1993$.

6 ）藤原朋樹, 真崎正美, 皆藤彦義, 他：鼻腔にみられ た神経線維腫の一症例.耳展 $36: 614-618$, 1993.

7 ) 犬塚一男, 兵 行彦, 森本高彦, 他: 鼻副鼻腔神経 鞘腫の一例. 耳鼻臨床 補 $16: 79-86,1987$.

8 ）小塩勝博, 大橋伸一, 林 弘太郎：鼻腔内に生じた 神経線維腫症例. 高山赤十字病院紀要 $17 ： 103-$ 109, 1993.

9 ）日野原正, 宮下賢次, 吉見充徳：耳鼻咽喉科領域の 神経鞘腫について. 耳展 $13: 11-17,1970$.

10) Shugar JM, Som PM, Biller HF, et al : Peripheral nerve sheath tumors of the paranasal sinus. Head and Neck Surg 4: 72-76, 1981.
11）池田勝久, 草刈 潤, 郭 安雄, 他: 上顎神経鞘腫 の一症例. 耳喉 $57: 67-71,1985$.

12）鈴木政治, 中村英生, 山岸益夫, 他：篩骨洞神経鞘 腫の一例. 耳鼻 $34: 1159-1162,1983$.

13) Das Gupta TK, Brasfield RD, Strong EW, et al: Benign solitary schwannomas (neurilemmomas). Cancer 24: 355-366, 1969.

14) Leon B: Tumors of the nervous system. In: Surgical pathology of the Head and Neck, ed by Leon B. Marcel Dekker, New York, 1985, pp662663.

15）盛川 宏, 田部哲也, 中屋宗雄, 他：鼻副鼻腔神経 鞘腫の一症例. 耳喉頭頝 69(13)：963-966, 1997.

16）田中一仁, 増田正純, 菅家 稔, 他: 耳下腺内の顔 面神経鞘腫の 2 例. 耳喉頭䅡 71（8）：494-499, 1999.

(2001 年 2 月 13 日受稿, 2001 年 4 月 10 日受理) 別刷請求先 $\overline{\mathbf{T}} 737-0134$ 吳市広多賀谷 $1-5-1$ 中国労災病院耳鼻咽喉科 田代 亨 Tel 0823-72-7171 Fax 0823-74-0371 